\title{
MUDÂRABE AKDİNDE ORTAYA ÇIKAN ANLAŞMAZLIKLARIN ÇÖZÜMÜNDE ESAS ALINAN İLKELER -OSMANLI UYGULAMALARI ÖZELINNDE-
}

\section{The Principles for the Resolution of the Disputes Arising in the Mudarabah Contract \\ - Based on the Ottoman Practices -}

\author{
Nasi ASLAN1 \\ Hasan KAYAPINAR ${ }^{2}$
}

\begin{tabular}{cr}
\multicolumn{2}{c}{ Makale Bilgileri } \\
\hline Geliş Tarihi: & 28.10 .2020 \\
Kabul Tarihi: & 16.11 .2020 \\
Yayın Tarihi: & 25.12 .2020
\end{tabular}

Özet

Şirket olgusu eski zamanlarindan beri mevcut olup, İslam tarihinde de Hz. Peygamber (s.a.s.) zamanindan beri uygulanmaktadır. Bu tarihi tecrübe içinde şirketin meşrûiyeti noktasinda bir ihtilaf bulunmamaktadır. Genel anlamda bir ortaklık türü olan mudârabe de bu kapsamda değerlendirilebilir.

Mudârabe, terim olarak bir ticari ortaklığ ifade etmekte olup ortaklardan birinin sermaye koyduğu, diğerinin ise bu sermayeyi işletmekle yükümlü olduğu bir şirket türüdür. Mudârabenin hukuki konumu ile ilgili Hanefi kaynaklara bakıldığında bu ortaklık türünün kıyasa aykırı olduğu vurgulanmaktadır. Dolayısıyla mudârabenin meşrûiyeti bazı özel delillere binaen istihsâna dayanmaktadır. Mudârabe akdi mahiyetinde farklı akitler barındırmaktadır. Sermaye sahibi ortaklık sermayesini mudâribe (sermayeyi çalıştıracak olan kişi) teslim etmesiyle bu para emanet, mudâribin sermaye ile alışveriş yapmaya başlamasıyla mudârib vekil, ortaklık neticesinde kâr elde edilmesiyle de mudârib kâra ortak olmaktadır.

Fıkıh eserlerinde bahsedildiği üzere mudârib malın kendisine teslim edilmesiyle birlikte bu malda emanet hükümleri geçerlidir. Buna göre mudâribin herhangi bir kasdı bulunmaksızın mudârabe malının zayi olması durumunda, mudâribin sorumluluğu söz konusu olmaz. Bu durumda zarar sermaye sahibine ait olacaktır. Diğer taraftan kârın olup olmadığı noktasında anlaşmazlık vukuunda mudâribin beyanı geçerli sayılmış, aksini ispat yükümlülüğü sermaye sahibine yüklenmiştir.

Çalışmada teorinin yanında kadı sicilleri ile fetva kitaplarına yansıyan mudârabe ortaklığına ilişkin hükümler ve tartışmalar üzerinden Osmanlı Devleti'ndeki mudârabe uygulamaları incelenmiştir. Özellikle anlaşmazlık durumunda esas alınacak ilkeler üzerinde durulmuştur.

Mudârabe ortaklığı pratikte ayrıntılı bir prosedür gerektirmemektedir. Diğer taraftan farklı yetenek ve imkanlara sahip insanları yani sermayeye sahip olmasına karşın ticaretle uğraşamayan kişiler ile ticari yeteneğe sahip olup da sermayeye sahip olmayan kişileri bir araya getiren bir şirket olmasindan ötürü sıklıkla tercih edilen bir ortaklık çeşididir. Nitekim şer'iye sicillerine bakıldığında en yaygın olan ortaklık uygulamasının mudârabe uygulaması olduğu görülmektedir.

Mudârabe ortaklığının işleyişine bakıldığında bazı problemleri de barındırdığı görülmektedir. Şöyle ki inisiyatifin daima mudâribe ait olduğu, bunun da fikıh usülündeki ıstıshâbü'l-hal ilkesine dayandığı

\footnotetext{
${ }^{1}$ Prof. Dr., Çukurova Üniversitesi/İlahiyat Fakültesi/Temel İslam Bilimleri Bölümü/İslam Hukuku Anabilim Dalı, nasiaslan@cu.edu.tr, https://orcid.org/0000-0002-0871-5102

2 Arş. Gör. Dr., Çukurova Üniversitesi/İlahiyat Fakültesi/Temel İslam Bilimleri Bölümü/İslam Hukuku Anabilim Dalı, hasankayapinar03@hotmail.com,0000-0001-8752-463X
} 
görülür. Şöyle ki mudârib bu ortaklıkla ilgili hiç kâr etmediğini söylese onun sözüne itibar edilmesi gerekmektedir. Çünkü aslolan kârın olmamasıdır. Zira öteden beri devam eden kârın yokluğudur. Ancak bunun hilafina bir delil sabit olduysa o zaman kârın varlığına hükmedilir. İşte bu anlayışın gerek teorik açıdan gerekse uygulamada mudârabe ile ilgili birçok probleme neden olması meselenin en zayı noktasını oluşturmaktadır. Bunun sonucu olarak sermaye sahipleri ortaklığın bütün riskini göğüsleme yerine risk unsuru içermeyen murâbaha uygulamasını tercih edebilir. Böylelikle Osmanlı uygulamalarına dair kayıtlarda da görüleceği üzere murabahanın neden en çok tercih edildiği daha anlaşılabilir olmaktadır.

Anahtar Kelimeler: İslam hukuku, Şirket, Mudârabe, Istıshâb, Osmanlı uygulaması

\section{Giriş}

Yapısı itibarıyla insanın sosyal bir varlık olduğu kabul edilir. Bunun anlamı insanın başka insanlarla bir arada yaşamaya uygunluğu, onlarla iş birliği yapmak durumunda olduğudur. İçinde yaşadığımız sosyal çevreye baktığımızda bu tespitin oldukça yerinde olduğu görülmektedir. İnsanların iş birliği yaptığı alanlardan biri de şüphesiz ki ekonomiye ilişkin sahalardır. İktisat alanındaki iş birliği kurumlarına şirket adı verilmekte olup çok eski zamanlardan beri insanların şirket kurduğu bilinmektedir.

Hayatın pek çok alanına dair normlar koyan İslam hukuku şirketler hakkında da hukukî düzenlemeler yapmış, taraflar arasında haksız kazancın önüne geçebilmek için birtakım kurallar ortaya koymuştur. Dolayısıyla bu kurallar çerçevesindeki ticari ortaklıkların hukukî varlığı tanınmış ve tarafların hakları koruma altına alınmıştır. İslam hukukunun temel kaynağ1 olan Kur'an-1 Kerim ve sünnette şirket konusu yer almakta olup Kur'an'da ortaklığın hukuki boyutundan ziyade ahlakî yönüne atıfta bulunan bir ayet bulunmaktadır. ${ }^{1}$ Buna karşın hadis külliyatında ahlakî ve hukukî açıdan şirket kurumuna yer verilmiştir. Nitekim bazı hadis kitaplarında ortaklık hakkındaki hadislerin toplandığı özel bölümler bulunmaktadır. ${ }^{2}$

Serahsî (v. 483/1090) şirket kurumunun İslam'dan önce de mevcut olduğunu ifade etmiş, Hz. Peygamber'in (s.a.s.) bu uygulamayı onayladığını, bizzat kendisinin ticari ortaklıklar kurduğunu ve süregelen zaman içinde ticari ortaklıkların meşrûiyeti noktasında muhalif görüş bulunmadığını aktarmıştır. ${ }^{3}$

Fıkıh kitapları şirketlerin ağırlıklı olarak sahih bir şekilde kurulması ve devam etmesi için gerekli olan şekil şartlarını ele almaktadır. Fıkhın uygulamaya yönelik pratik kuralları konu edinen bir ilim olduğu dikkate alındığında bu durum anlaşılabilir olsa gerektir. Ancak fıkıh kitapları şirket konusundaki şekil şartlarını ele almadan önce şirketi kuracak tarafların ahlaki yükümlülüklerini de hatırlatmaktadır. Nitekim bazı fürû-i fıkıh kitapları şirket bahsinin giriş kısmında tarafların Allah'a karşı sorumlu olduklarını hatırlatma sadedinde bazı hadisleri zikretmekte ve bu yönde hatırlatmalar yer almaktadır. ${ }^{4}$

\footnotetext{
${ }^{1}$ Sa'd, 38/24.

2 Ebû Abdullah Muhammed b. İsmail Buhârî, Sahîh'ül-Buhârî, ed. Halil b. Me'mun Şiha (Beyrut: Daru'l-Marife, 2010), "Şirket".

${ }^{3}$ Ebû Bekr Şemsüleimme Muhammed b. Ahmed b. Sehl Serahsi, el-Mebsut (Beyrut: Daru'l-Marife, ts.), 11/151.

${ }^{4}$ Ebû İshak Cemaleddin İbrâhim b. Ali b. Yusuf Şirâzî, el-Mühezzeb fì Fıkhi'l-Imam eş-Şafiù, ed. Zekeriya Umeyrat (Beyrut: Dârü'l-Kütübü'l-İlmiye, 1995), 2/156; Ebül-Fazl Mecdüddin Abdullah b. Mahmûd b. Mevdud Mevsîlî, elİhtiyâr li-Ta'lîli'l-Muhtâr, ed. Halid Abdurrahman el-Akk (Beyrut: Daru'l-Marife, 2007), 3/11.
} 


\section{1. İslam Hukukunda Şirket Kavramı}

Mudârabe akdinin İslam hukukundaki şirket bahsi ile ilişkili olmasından ötürü mudârabe konusunu ele almadan önce İslam hukukundaki şirket teorisini kısaca gözden geçirmek konunun daha iyi anlaşılmasına katkı sağlayacaktır. Bu bölümde şirket konusunun temel sınıfları genel hatlarıyla sunulacak, detaylardaki tartışmalara yer verilmeyecektir.

Şirket kelimesi sözlük anlamı itibarıyla iki kişinin mallarını karıştırması, ortaklık kurması anlamindadır. ${ }^{5}$ Şirketin terim anlamı ise bir malda, bir amelde veya bir kârda en az iki kişinin ihtiyarî ya da zarurî olarak ortak olmalarıdır. ${ }^{6}$

Fürû-i fikıh kitaplarında şirket bölümü müstakil bölümlerde ele alınmaktadır. Hanefí mezhebinin taksimine göre şirketler iki sınıf içinde ele alınmaktadır. Bunlar mülk şirketi ve akit şirketidir.

Mülk şirketi, ortaklığa konu olan malın bizzat malın aynında ortak olmayı ifade etmektedir. Mülk şirketi de ikiye ayrılmaktadır. Bunlar cebri şirket ve ihtiyari şirkettir. Cebri şirket, isminden de anlaşılacağı üzere tarafların iradeleri haricinde kurulan ortaklıktır. En az iki kişinin mallarının ayrılamayacak şekilde karışması ve tarafların yeni malda ortak olmaları ya da miras kalan malda varislerin durumu bu sınıf için örnek olarak gösterilebilir. İhtiyari mülk şirketi de iki kişinin mallarını isteyerek karıştırmaları, iki kişinin bir malı satın alması, bir kişinin malını iki kişiye hibe etmesi, vasiyet etmesi ve bunların bu bağışı kabul etmesi gibi iradeleri ile malın aynında ortak olmayı ifade etmektedir. Bu şirket türünde ortakların her biri diğerinin payı hakkında tasarrufta bulunamaz. ${ }^{7}$

Akit şirketi, ortaklığa konu olan sermaye açısından para ortaklığı, iş ortaklığ1 ve kredi ortaklığı olarak üçe ayrılmaktadır. Buna karşın ortaklar arası şirket üzerindeki yetki ve tasarruf hakkı açısından mufâvada ve inân sınıflarına ayrılmaktadır. ${ }^{8}$

Para ortaklığı iki kişinin ortaya para koyarak bir şey almak ve satmak üzere anlaştığı, ikisinin de nakit para koyarak kurdukları şirket türüdür. Para ortaklığının sahih olarak kurulabilmesi için şirkete konu olacak paranın akit esnasında ya da şirketin mal satın alacağı anda hazır bulunması gerekmektedir. Bundan dolayı gâib olan kişinin bu şirketi kurması mümkün değildir. Aynı şekilde alacak üzerine de şirket kurulamaz. Şirketin kurulması için ortaya konan sermayenin nakit para olması gerekmektedir. Bundan dolayı külçe altın bu ortaklık türü için sermaye olarak kabul edilmemektedir. Semerkandî’nin (v. 539/1144) ifadesine göre külçe altın şirketler bahsinde ticaret malı kabul edilirken sarf bahsinde para olarak kabul edilmektedir. ${ }^{9}$

\footnotetext{
${ }^{5}$ Ebü'l-Feyz Muhammed el-Murtazâ b. Muhammed b. Muhammed b. Abdirrezzâk ez-Zebîdî, Tâcu'l Arûs Min Cevâhiri'l Kâmûs, ed. Mustafa Hicâzî (Kuveyt: Daru Türasi'l-Arabî, 1993), 27/223; Asım Efendi, el-Okyânûsu'l-Basît fì Tercemeti'l-Kâmûsi'l-Muhît Kâmûsu'l-Muhît Tercümesi, ed. Mustafa Koç (İstanbul: Türkiye Yazma Eserler Kurumu Başkanlığ1, 2012), 5/4255.

6 Ömer Nasuhi Bilmen, Hukuk-ı İslamiye ve Istılâhâtı Fıkhiye Kamusu (İstanbul: Bilmen Yayınevi, 1976), 7/63.

${ }^{7}$ Ebü'l-Hüseyin Ahmed b. Ebî Bekr Muhammed b. Ahmed el-Kudûrî, el-Muhtasar, ed. Kami Muhammed Muhammed Avida (Beyrut: Daru'1-Kütübi'l-ìlmiye, 1997), 110; Mevsîlî, el-İhtiyâr, 3/12.

8 Efendi Ali Haydar, Dürerül-Hukkam Şerhu Mecelleti'l-Ahkam, çev. Raşit Gündoğdu - Osman Erdem (İstanbul: Osmanlı Yayınevi), 3/367; Beşir Gözübenli, "Şirket", Türkiye Diyanet Vakfi İslam Ansiklopedisi (İstanbul: TDV Yayınlar1, 2010), 39/199.

${ }^{9}$ Ebû Bekr Alaeddin Muhammed b. Ahmed b. Ebû Ahmed Semerkandî, Tuhfetül-Fukahâ (Beyrut: Daru'l-Kütübi'lİlmiye, 1983), 3/6.
} 
İş ortaklığ ise iki kişinin herhangi bir işi birlikte yapmak ve kazandıklarını paylaşmak üzere yaptıkları anlaşma neticesinde kurulan ortaklıktır. İş ortaklığında bir ortağın aldığı işten diğeri de sorumludur. Diğer taraftan ortaklardan birisine diğerinden daha fazla iş verilse dolayısıyla bir ortak diğerine göre daha fazla çalışsa hatta diğeri hiç iş yapmasa da kazanç başta anlaştıkları üzere eşit olarak paylaş1lır. ${ }^{10}$

Kredi ortaklığı da ellerinde sermayesi olmayan iki ortağın veresiye mal alıp bunu satmak ve kârını paylaşmak üzere kurdukları ortaklık türüdür. Kredi ortaklığında ortakların her biri diğerinin vekili konumundadır. Şirket kurulurken ortaklar satın alınan malın aralarında eşit bir şekilde olacağı üzere anlaşmışlarsa kâr eşit bir şekilde paylaşılmalıdır. ${ }^{11}$

Yukarıda belirtildiği üzere şirket üzerindeki tasarruf yetkisi açısından şirketlerin mufâvada ve inân olmak üzere iki türü bulunmaktadır. Mufâvada kelime anlamı itibarıyla bir işi başkasına havale etmek, tam yetkiyle vekil kılmak anlamındadır. Mufâvada şirketi de kelime anlamıyla ilişkili olup ortakların bütün malıyla katıldığı, her ikisinin de bütün ticaretini kapsayan, sermayede ve tasarruf hakkında eşitliği gerekli k1lan ortaklık türüdür. ${ }^{12}$

Mufâvada ortaklığına eşitlik ilkesi hakim olduğundan dolayı hukukî statüsü farklı olan kişilerin bu ortaklığı kurmalarının caiz olmadığ kabul edilmiştir. Bu minvalde mufâvada ortaklığının âkil, bâliğ, hür Müslümanlar arasında kurulabileceği kabul edilmiştir. Başka bir ifadeyle hür ile mükâteb bile olsa köle, sabî ile bâliğ kişi arasında mufâvada şirketi kurulamaz. Zira bu kişiler arasında hukuken tasarruf yetkisi açısından eşitlik söz konusu değildir. ${ }^{13}$

Mufâvada şirketinde aynı zamanda ortaklar arasinda hem vekalet hem de kefalet akdinin kuralları geçerlidir. Yani ortaklardan birisinin şirket adına yaptığı bir işlem şirket için, başka bir ifadeyle diğer ortak için de geçerli olup, her iki ortak açısından da bağlayıcı olur. Ortaklar arasında kefalet akdinin kurulmasının anlamı ise ortaklardan birisinin, diğerinin şirket adına yaptığı işlemde müteselsil kefil sayılacağıdır. Dolayısıyla ortaklardan birisinin şirket adına borca girmesi durumunda diğer ortak da bu borca girmiş sayılır ve alacaklı ortaklardan herhangi birisine başvurabilir. ${ }^{14}$

Yukarıda ifade edildiği üzere mufâvada şirketi iki kişinin eşit bir şekilde paraları ortaya koyması ve kârın da eşit olarak paylaştırılması kuralına dayanmaktadır. Bu kural gereği taraflardan birisine miras mal kalması, hibe edilmesi gibi durumlarda ilgili tarafın malı artacağ için bu durumda mufâvada ortaklığ bozulur ve bu şirket inân şirkete dönüşür. ${ }^{15}$

Hanefî mezhebinde şirketlerin gayr-1 lazım bir akit olduğu kabul edilmektedir. Yani taraflar istedikleri zaman karşı tarafın iradesinden bağımsız bir şekilde yani tek taraflı irade beyanı ile ortaklığ1 sonlandırabilir. Ancak şirket akdini feshetmenin bazı şartları bulunmaktadır. Öncelikle fesih işleminin diğer ortağın bilgisi dahilinde olması gerekmektedir.

\footnotetext{
10 el-Kudûrî, el-Muhtasar, 111.

11 el-Kudûrî, el-Muhtasar, 111, 112.

12 Abdülganî b. Talib b. Hammade ed-Dımaşki Meydanî, el-Lübâb fi Şerhi'l-Kitâb, ed. Abdürrezzâk el-Mehdi (Beyrut:

Dârü'l-Kitâbi'l-Arabî, 2012), 2/53.

${ }_{13}$ Meydanî, el-Lübâb, 2/54.

${ }^{14}$ Mevsîlî, el-íhtiyâr, 3/13.

${ }^{15}$ Ebû Ca'fer Ahmed b. Muhammed b. Selâme Tahâvî, Muhtasarü't-Tahâvî, ed. Ebü'l-Vefâ el-Efganî (Kahire: Dârü'lKitâbi'l-Arabi, 1370), 107.
} 
Zira ortağın bilgisi olmaksızın yapılan feshin ona zarar vermesi muhtemeldir. Diğer taraftan fesih kararının diğer ortağa bildirilmesi hukuk tekniği açısından da gereklidir. Zira yukarıda belirtildiği üzere şirket anlaşması vekalet akdini de zımnında barındırmaktadır. Vekaletteki kurala göre vekilin azledildiğinin vekile bildirilmesi gerekmektedir. Dolayısıyla vekalet akdini de içeren şirket akdinde de fesih kararının ortağa bildirilmesi gerekmektedir. ${ }^{16}$

Şâfîi mezhebine göre şirketin sahih bir şekilde kurulabilmesi için ortakların şirket sermayesi olarak ortaya koydukları malların fiziken karışması gerekmektedir. Diğer taraftan Şâfiî mezhebinde mufâvada şirketinin batıl olduğu ileri sürülmüştür. Zira tarafların birbirinin mallarına vekil ve kefil olarak kabul edilmesini hakkaniyete aykırı bulmuşlardır. Diğer taraftan Şâfî̀ mezhebindeki genel kanaate göre ortaklardan birisi diğerinin malında ancak onun izni ile tasarrufta bulunabilir. Buna göre şirket akdinin kurulmasından önce taraflardan her ikisi de şirket malında karşı tarafa tasarruf izni verirse ortakların her ikisi de şirket malının bütününde tasarrufta bulunabilir. Aynı şekilde şirket akdi kurulurken ortaklardan birisi ortağına kendi malında tasarruf izni verse, diğeri ise bu izni vermese, izin verilen ortak şirket malının bütünü için tasarrufta bulunabilir. Ancak izin verilmeyen ortak sadece şirket malının yarısı yani kendi payı hakkında tasarrufta bulunabilir ve onunla ticaret yapabilir. ${ }^{17}$

İnân şirketinde ise ortakların farklı sermayelerle şirket kurmaları caizdir. Zira bu şirket türünün ortakların yaptığı ticaretin bütününü kapsaması mümkün olduğu gibi bir kısmını da kapsayabilir. ${ }^{18}$

\section{Mudârabe Akdi}

Mudârabe kelimesi Arapça ضرب (darabe) fiilinin müfâale kalıbının masdarıdır. Darabe kelimesi sözlük anlamı itibarıyla vurmak demektir. Bu fiil yeryüzü ile birlikte kullanılması durumunda darabe kelimesinin anlamı yürümek olur. Kişi ayağıyla yeryüzüne vurarak ilerlediği için bu anlam verilmiştir. ${ }^{19}$

Mudârabe, terim olarak bir ticari ortakllğı ifade etmekte olup ortaklardan birisinin sermaye koyduğu, diğerinin bu sermayeyi işletmekle yükümlü olduğu şirket türüdür. Bu ortaklığa mudarebe isminin verilmesinin sebebi ortaya konan sermayeyi işleten kişinin kâr elde etmek amacıyla çalışmasını ifade etmek içindir. Şâfiî mezhebinde ise bu ortaklığa kırâz ismi verilmekte olup bu kelime borç verme anlamındaki karz (قرض) kelimesinden türemiştir. Karz kelimesi sözlük anlamı itibarıyla 1sırmayı, kesip parça koparmayı ifade etmektedir. ${ }^{20} \mathrm{Bu}$ ortaklığa kırâz isminin verilmesi sermaye sahibinin parasından kesip koparmasını ifade etmeye yönelik olsa gerektir. Bu iki farklı isimlendirmeden hareketle ortaklığa Hanefí mezhebinin sermayeyi çalıştıran taraf açısından baktığı, Şâfiî mezhebinin ise sermaye sahibi açısından baktığı söylenebilir.

\footnotetext{
${ }^{16}$ Ebû Bekr Alaeddin Ebû Bekr b. Mes'ud b. Ahmed Kâsânî, Bedâiü’s-Sanâi' fî Tertibi'ş-Şerai', ed. Ali Muhammed Muavvad (Beyrut: Dar'ul-Kütübi'l-ìlmiye, 2003), 7/545.

17 Sirâzî, el-Mühezzeb, 2/157, 158.

18 Kâsânî, Bedâiü's-Sanâi', 8/5.

19 Ebû'l-Kâsım Hüseyn b. Muhammed b. er-Râgib El-İsfahânî, el-Müfredât fì Garîbi'l-Kurân, thk. Ṣafvân 'Adnan edDâvûdî (Dımaşk: Daru'l-Kalem;Daru'ş-Şâmiyye, ts.), 295.

${ }^{20}$ Şirâzî, el-Mühezzeb, 2/226.
} 
Mudârabenin hukuki konumu ile ilgili Hanefí fikıh kaynaklarında bu ortaklık türünün kıyasa aykırı olduğu belirtilse de onun meşruiyeti bazı özel delillere binaen istihsânen kabul edilmiştir. Kâsânî (v. 587/1191) mudârabe akdinin meşrû olduğuna dair Kur'an'dan, sünnetten, icmadan istidlalde bulunmuştur. Kazancin meşrû olduğunu ifade eden ayetlerin mudârabe akdinin de meşrûiyetine delalet ettiğini ifade etmiştir. Kâsânî ayrica Hz. Abbas'in (v. 32/653) mudârabe ortaklığı yaptığını, bu ortaklık için bazı şartlar ileri sürdüğünü, Hz. Peygamber’in de (s.a.s.) bu ortaklığı onayladığını ve bu rivayetin de mudârabenin cevazını gösterdiğini ifade etmiştir. İcma deliline gelince, Hz. Peygamber (s.a.s.) zamanından beri insanların mudârabe ortaklığı yaptığını ve ulemanın bu ortaklığı meşrû kabul ettiğini söylemiştir. ${ }^{21}$

Hanefî fürû-i fikıh eserlerinde mudârabenin kıyasa aykırı olduğu kabul edilmekte, bu ortaklığın meşrûiyet kaynağının istihsân olduğu vurgulanmaktadır. Yukarıda ifade edildiği üzere istihsân sebepleri olarak kitap, sünnet ve icma zikredilmektedir. Bunun yanında zaruret de istihsân sebebi olarak zikredilmektedir. Şöyle ki insanlar mahiyet itibarıyla muhtelif yapıda ve farklı imkanlara sahiptir. Maddi varlığa sahip olan pek çok kimse ticarî kabiliyetten yoksun olabilir ve bundan dolayı ticaret yapamazlar. Buna karşın elinde sermayesi olmayan pek çok kimse de ticari kabiliyete sahip olabilir. Ne var ki maddi imkânsızlık sebebiyle bu kabiliyetini kullanamaz. İşte mudârabe ortaklığı tam da bu noktada devreye girmekte, toplumdaki farklı imkanlara sahip insanları bir araya getirmektedir. Dolayısıyla mudârabe akdi toplumsal bir zorunluluk olarak karşımıza çıkmaktadır. ${ }^{22}$

Farklı imkanlara sahip insanların bir araya gelerek iş birliği yapmalarının neticesinde gerek bireysel gerekse de toplumsal büyük başarıların yakalandığı görülmektedir. Nitekim 1946 yılında Amerika'da başlayıp 1970'li ve 1980'li yıllarda batı dünyasında yaygınlaşan ve çok başarılı sonuçlar elde edilen risk sermayesi ortaklığı mahiyet itibarıyla mudarebe ortaklığına benzemektedir. ${ }^{23}$

Mudârabe akdi mahiyetinde farklı akitler barındırmaktadır. Sermaye sahibi ortaklık sermayesini mudâribe (sermayeye çalıştıracak olan kişi) teslim etmesiyle bu para emanet, mudâribin sermaye ile alışveriş yapmaya başlamasıyla mudârib vekil, ortaklık neticesinde kâr elde edilmesiyle de mudârib, kâra ortak olmaktadır. ${ }^{24}$

Mudârabe şirketi, tarafların irade beyanıyla, mudârabe ortaklığına açık bir şekilde delalet eden lafızlar ile kurulmaktadır. Mudârabe ortaklığında mudârib sermaye sahibinin izin verdiği kadarıyla yetkilidir. Yani sermaye sahibinin izin verdiği alanlarda ve şehirlerde iş yapmak zorundadır. ${ }^{25}$ Zira ortaklığa konu olan sermayenin sahibi kendisidir. Sermayenin zayi olması durumunda zarar edecek olan kendisidir. Dolasıyla parasının güvendiği alanlarda ve

\footnotetext{
${ }^{21}$ Kâsânî, Bedâiü's-Sanâi', 8/8.

22 Kâsânî, Bedâiü's-Sanâi', 8/8; Mevsîlî, el-ïhtiyâr, 3/19.

${ }^{23}$ Murat Çizakça, Risk sermayesi özel finans kurumları ve para vakıfları. (İstanbul: İslami İlimler Araştırma Vakfı, 1993), 16; Servet Bayındır, İslam hukuku penceresinden faizsiz bankacılık. (İstanbul: Rağbet Yayınlar1, 2005), 107113.

${ }^{24}$ Şirâzî, el-Mühezzeb, 2/232; Mevsîlî, el-İhtiyâr, 3/19; Nuri Kahveci, Mukayeseli İslam Borçlar Hukuku (Şirketler İlaveli) (İstanbul: Hikmetevi Yayınları, 2015), 284.

${ }^{25}$ Meydanî, el-Lübâb, 2/61.
} 
şehirlerde kullanılmasını isteme hakkı olmalıdır. Buna karşın sermaye sahibi mudâribe mutlak olarak izin de verebilir. Yani herhangi bir kayıt koymaksızın mudâribe istediği yerde, istediği ticareti yapma yetkisi verebilir.

\section{Mudârebeye Esas Olan Hükümler}

Mudârabe akdinin en önemli hükümlerinden birisi de sermaye sahibi ile mudârib kâr1 oran üzerinden paylaşmalardır. Dolayısıyla herhangi birisi sabit ücret almak üzere şart koşsa mudârabe akdi fasit olacaktır. ${ }^{26}$ Osmanlı uygulamasında kâr oranıyla ilgili bir anlaşmazlık durumunda (kâr oranın kararlaştırılmadığı iddia ediliyorsa) örf ve teamül gereği bunun yarı yarıya olduğu kabul edilmektedir. ${ }^{27}$

Fürû-i fikıh kitaplarında mudârabe ortaklığından mudâribin kâr elde etmeme ihtimali de ele alınmıştır. Yukarıda belirtildiği üzere mudârib malın kendisine teslim edilmesiyle bu malda emanet hükümleri geçerlidir. Bunun anlamı ortaklığa konu olan malın mudâribin herhangi bir kasdı bulunmaksızın zayi olması durumunda mudâribin sorumluluğunun söz konusu olmamasidır. Bu durumda zarar sermaye sahibine ait olacaktır. ${ }^{28}$

Mudârib malı teslim aldıktan sonra bu malla ticarete başlasa, bir mal satın alsa, bu aşamada da mudârib sermaye sahibinin vekili konumundadır. Bunun anlamı ise mudârabe sermayesi ve ortaklık adına alınan mal sermaye sahibine ait olup mudâribin dahil olması söz konusu değildir. Dolayısıyla bu aşamada mudâribin kasdı olmaksızın ortaklık adına alınan malda zarar meydana gelmesi durumunda zarar yine sermaye sahibine ait olacaktır. Zira mudârib bu aşamada sermaye sahibinin vekili konumundadır ve hukuken onun adına işlem yapmaktadır.

Mudârabe ortaklığının en son aşamasında, ticaretin tamamlanıp kâr elde edilmesi durumunda mudârib sermeye sahibinin ortağı olarak kabul edilir ve kâr, başta anlaşılan oran üzerinden paylaşılır. Buna karşın mudârib sermaye sahibinin izin verdiği sınırlar çerçevesinde kalmak şartıyla zarar etse sermayeyi tazmin etmez. Zira bu aşamada sermaye sahibinin vekili konumundadır. Mudârabe akdinin fasit hükmünü alması da bu sonucu değiştirmeyecektir. ${ }^{29}$

Mudârabenin muhtelif durumlarda farklı hükümler alacağı kabul edilmiştir. Buna göre mudâribin girişimlerinden sonra mudârabe akdinin fesada uğraması ve feshedilmesi halinde akit icâre akdine dönüşecektir. Zira mudârib sermaye sahibinin malını işletmiş, onun için emek sarfetmiştir. Bu aşamada mudârabe akdinin feshedilmesi ve mudâribin kârdan pay alamaması sermaye sahibinin sebepsiz zenginleşmesine yol açacaktır. Bundan dolayı mudârib ecir-i has kabul edilmiş ve ecr-i misil, piyasa şartlarında yaptığı işin ücretini alması kararlaştırılmıştır. ${ }^{30}$

\footnotetext{
${ }^{26}$ Şirâzî, el-Mühezzeb, 2/228; Bilmen, Istılâhâtı Fıkhiye Kamusu, 7/103, 104.

27 Mehmed Aziz Çavuşzade, Dürrü's-sukuk. (İstanbul: Matbâa-i Âmire, 1288), 2/171, 172; Mustafa Avc1, Türk Hukuk Tarihi (Konya: Atlas Akademi, 2017), 522.

28 Şemseddin Hatib Muhammed b. Ahmed Şirbînî, Muğni'l-Muhtac ila Marifeti Meânî Elfazi'l-Minhac, ed. Muhammed Halil Îtânî (Beyrut: Daru'1-Marife, 1997), 2/410.

${ }^{29}$ Kâsânî, Bedâiü's-Sanâi', 8/18, 27.

${ }^{30}$ Semerkandî, Tuhfetül-Fukahâ, 3/21.
} 
Mudârib sermaye sahibinin verdiği izin ve yetkiyi aşarsa sermayeyi gasbetmiş gibi kabul edilir ve sermayeyi tazmin etmesi gerekir. Zira sermaye sahibinin parasını onun izni dışında kullanmıştır. Bu durumda yaptığı amelin karşılığı da söz konusu değildir. ${ }^{31}$

Mudârabe ortaklığına konu olan malın bir kısmı zayi olsa, bu zayi kısım ortaklığın anaparasından değil kârdan düşülür. Zira anapara asıl, kâr tâbidir. Zararın öncelikle tâbi olana sarf edilmesi gerekmektedir. Ancak kâr zararı karşılamazsa zarar anaparadan karşılanır. Mudârib bunu tazmin etmez, ancak mudâribin de ameli zayi olduğuna hükmedilmiş, yaptığı işlerin karşıllı̆ında alacağı yoktur. Zararın sermaye sahibi ve mudârib arasında paylaştırılması kararlaştırılsa da bu anlaşmanın hükümsüz olup zarar sermaye sahibinden karş1lanmalıdır. ${ }^{32}$

Mudârabe ortaklığında akdin hukuku mudâribe aittir. Mudârabe ortaklığında anapara, sermaye sahibine ait olsa da akdi yapan mudâribtir. Dolayısıyla malın ve semenin teslim alınması ve teslim edilmesi, aldığı ya da sattığı malın ayıplı çıkması durumunda ayıp muhayyerliğinden dolayı mal sahibine kendisi başvurma ve kendisine başvurulma noktalarında muhatap mudarib olmalıdır. ${ }^{33}$

Modern dönemde bir şirket olarak mudârabeye yönelik eleştiriler de mevcuttur. Buna göre mudârabe emanete dayanan bir ilisski ve kimi zaman da vekâlet mesabesinde konumlandırılmıştır. Bu şekilde bir iş birliği sonucu kazancın elde edilmesi durumunda şirket sayılması ve ayrıca sermaye sahibinin tek taraflı zararı çekmesi gibi cihetlerden dolayı eleştirilmiştir.

Yukarıda aktarılan eleştirinin yerinde olduğu söylenebilir. Nitekim Mecelle'nin 1428. maddesinde zarar ve ziyanın her halde sermaye sahibine ait olduğu, taraflar aksini kararlaştırsa da bu kararın hükümsüz olduğu ifade edilmiştir. ${ }^{34}$

Diğer bir eleştiri de mudârabenin ribâ yasağından kurtulmaya dönük şerî̀ bir hile olduğu iddiasıdır. ${ }^{35}$ Ancak bu iddia gerek teorik anlamda gerekse uygulama bağlamında dikkate alındığında vakıaya ters düşer. Zira bilinmektedir ki doktrinde sermaye sahibi sadece kâr elde etmeyi şart koşarsa mudârabe ortakllğı fasit olur. Uygulamada ise şer'iye sicillerine bakıldığında ortaklığın fiili olarak işleyen en yaygın şirket şeklinin mudârabe olduğu görülür. Diğer taraftan işletmeden doğan anlaşmazlıkların ayrıntılarıyla yargıya yansımış olması bu iddiayı çürütmektedir. Fakat bu iddia murâbahaya dönük olsa kısmen anlaşılabilirdi. Zira şer'iye sicillerinde yer alan kayıtlar bu iddiayı bütünüyle nefyetmemektedir. Buradan da anlaşılan iddia sahibi bu eleştirisini murâbaha yerine mudârabeye yöneltmiş olup bu iki kavramı karıştırmıştır.

İşleyişte birçok problemlere neden olan ve kar-zarar anlaşmazlığında inisiyatifi daima mudâribe teslim eden bu anlayış araştırıldığında bunun esasının fikıh usülündeki ıstıshâbü'l-

\footnotetext{
${ }^{31}$ Mevsîlî, el-ihtiyâr, 3/20.

32 Bilmen, Istılâhâtı Fıkhiye Kamusu, 6/108.

${ }^{33}$ Kâsânî, Bedâiü's-Sanâi', 8/34.

${ }^{34}$ Ali Haydar, Dürerü'l-Hukkam, 3/446.

35 Joseph Schacht, Joseph Schacht, İslam Hukukuna Giriş, çev. Mehmet Dağ, Abdülkadir Şener., Ankara Üniversitesi İahiyat Fakültesi Yayınları, Anraka 1977, çev. Mehmet Dağ - Abdülkadir Şener (Anraka: Ankara Üniversitesi İlahiyat Fakültesi, 1977), 162.
} 
hal ilkesine dayandığı görülür. Buna göre mudârib bu ortaklıkla ilgili hiç kâr etmediğini söylese onun sözüne itibar edilmesi gerekmektedir. Çünkü aslolan kârın olmamasıdır. Zira öteden beri devam eden kârın yokluğudur. Ancak bunun hilafına bir delil sabit olduysa o zaman kârın varlığına hükmedilir. ${ }^{36}$ İşte bu anlayış gerek teorik açıdan gerekse uygulamada mudârabe ile ilgili birçok problemlere neden olması hasebiyle meselenin en zayıf noktasını oluşturmaktadır.

Burada bir yönden bakıldığında ciddi bir tenakuzun olduğu da söylenebilir. Zira bir taraftan istishab ilkesi delillerin en zayıfı olarak kabul edilmiş, ${ }^{37}$ diğer taraftan da bu ilkeye binaen zararın her durumda sermaye sahibine yüklenmesi gibi dâimî ve değişmez bir ilke vaz edilmiştir. Ayrıca konuya çok yönlü bakılsaydı yine istishab ilkesinden hareket edilip bu meselenin vasıf ıstıshâbına dahil edilmesi mümkün ve daha makul olabilirdi. Bu yaklaşım mal sahibini de koruyacak normatif bir ilkenin geliştirilmesinde daha etkili olabilirdi. Zira vasıf 1stıshâbı 1stıshâb çeşitleri içinde en güçlü olanıdır. Bu açıdan meseleye şöyle bakılması da mümkündür. Ticaretle uğraşıp belli bir tecrübeden sonra tacir vasfını kazanmış olmak vasıf 1stıshâbının bir gereğidir. Örfen bu vasfı kazanan bir tacirden kâr etmesi beklenir. Zarar etmesi ise arizi bir durumdur. Buradan hareketle mudârib ile mal sahibinin aralarında karzarar anlaşmazlığına dönük bir davada zararın taraflar arasında paylaşılması mümkün görülmelidir. Netice itibarıyla böyle bir yaklaşım inisiyatifin tamamen mudâribin uhdesine verilmesini önleyecektir.

\section{Osmanlı Hukukunda Mudârabe Uygulamaları}

Ayrıntılı bir prosedür gerektirmemesi nedeniyle mudârabe akdinin uygulamada yaygın bir ortaklık türü olduğu görülür. Ayrıca sermayesi olup da ticarete vakit ayıramayacak meşguliyetleri olanların sıklıkla bu ortaklığı tercih ettikleri müşahede edilmektedir. Buna göre Osmanlı döneminde müderris, müfti gibi ilmiye sınıfına ait görevlilerin hatta medrese talebelerinin bile mudârabe yoluyla paralarını işlettikleri görülmektedir. ${ }^{38}$

Şer'iye sicillerine bakıldığında en yaygın olan ortaklık uygulamasının mudârabe olduğu görülmektedir. Özellikle murâbahanın teknik anlamda şirket olduğu kabul edilmezse en yaygın uygulamanın mudârabe olduğu görülür. Fakat bunun küçük yerleşim yerlerinden ziyade ticaretin canlı olduğu şehir merkezlerinde cari olduğu müşâhede edilmektedir. $\mathrm{Bu}$ noktada murâbaha ve mudârabenin temel farklılık noktalarının belirtilmesi gerekirse, murâbaha, ticaret görüntüsü altında kâr garantili borç verme usulü olarak tanımlanabilirken; mudârabe kâr ya da zarar ihtimalini de barındıran ortaklık olarak tavsif edilebilir.

Mudârabe ortaklığında taraflar ileride doğabilecek anlaşmazlıklara meydan vermemek için akdin kuruluşunda sermaye miktarı, kâr oranı gibi ortaklığa dair hususları içeren bir sözleşme yaparak buna dair kadıdan hüccet tanzim ettirirlerdi. ${ }^{39}$ Uygulamaya bakıldığında sermaye sahiplerinin ticari işleyişi kontrol ettikleri, zaman zaman muhasebe yaptıkları ve

\footnotetext{
${ }^{36}$ Abdülkerim Zeydan, el-Vecîz fi Usûli'l-Fıkh (Dımaşk: Müessetü'r-Risale, 2006), 214

37 Ömer Faruk Habergetiren, "Mecelle Şârihi Ali Haydar Efendi ve "Mefkûd Risâlesi"”, İslam Hukuku Araştırmalar Dergisi 22 (2013), 497.

38 Çavuşzade, Dürrü's-sukuk., 2/171, 172.

39 Çavuşzade, Dürrü's-sukuk., 2/171.
} 
ileride doğabilecek anlaşmazlıkta ileri sürmek amacıyla şahit tuttukları ve bunu gerçekleştirdikten sonra fesih cihetine gidildiğinde de ilgili şahitleri ispat vasıtası olarak kullanıp sermaye ve kârı koruma yoluna gittikleri görülmektedir. ${ }^{40}$

Burada kadı sicilleri ve fetva kitaplarına yansıyan mudârabe ortaklığına ilişkin kayıtlar Osmanlı Devleti'ndeki mudârabe uygulamaları hakkında önemli fikirler vermektedir. Bu bağlamda Osmanlı kadı sicillerinde yer alan bir kayda göre Mehmet Çelebi isminde bir kişi Yorgi isminde birisine mudârabe ortaklığı için sekiz bin gümüş akçeyi teslim etmiştir. Daha sonra bu parayı sadece İzmir'de işletmesini söylediğini iddia etmektedir. Ancak mudârib olan Yorgi'nin İzmir dışına çıktığını, daha sonra da parayı İstanbul'a götürürken çaldırdığını iddia etmiş ve Yorgi'nin bu parayı tazmin etmesini istemiştir. Hükümde yer alan ifadeye bakıldığında da Mehmet Çelebi'nin iddiasını ispat edecek bir delil istendiği ancak Mehmet Çelebi'nin böyle bir delil ikame edemediği ifade edilmektedir. Daha sonra davalı Yorgi'den yemin istendiği ve Yorgi'nin de kendi dini üzerine yemin ettiği ve bu yeminin kabul edildiği belirtilmektedir. ${ }^{41}$

$\mathrm{Bu}$ hükümde fikıh açısından incelenmesi gereken iki temel husus bulunmaktadır. Bunların birincisi Müslüman bir vatandaşın ehl-i kitaptan bir vatandaş yani zimmî bir kişi ile mudârabe ortaklığı kurması meselesidir.

Kadı sicilinde yer alan yukarıdaki hükümde fikhi açıdan ele alınması gereken ikinci bir husus daha bulunmaktadır. Bu da mudaribin sermaye sahibinin izni dahilinde hareket etme zorunluluğu ve bu izin haricine çıkması halinde mal zayi olursa sermayeyi tazmin etmesinin gerekip gerekmediği konusudur.

Fıkıh kaynaklarına göre mudâribin sermaye sahibinin izin verdiği çerçevede hareket etme zorunluluğu bulunmaktadır. Bu izin dışında hareket etmesi durumunda sermayeyi gasp etmiş gibi kabul edilmekte ve bu malı tazmin etmesi gerekmektedir. ${ }^{42}$ Nitekim yukarıdaki hükümde de ifade edildiği üzere sermaye sahibi olan Mehmet Çelebi'den iddiasını ispatlamak için delil talep edilmiş ancak Mehmet Çelebi delil getirememiştir. Mehmet Çelebi'den delil istenmesinin amacı sermaye sahibinin sadece İzmir'de ticaret yapılmasının şart koşulduğuna hüküm verilmesi ve bu hükme binaen mudârib Yorgi'ye bu malın tazmin ettirilmesi olsa gerektir. Zira böyle bir hüküm doğurmayacaksa Mehmet Çelebi'den delil istenmesinin anlamı olmazd1. Diğer taraftan Mehmet Çelebi'nin delil getirememesi üzerine Yorgi'den yemin etmesi istenmiş, o da istendiği vecih üzerine yemin etmiştir. Bunun neticesinde Yorgi'nin lehine hüküm verilmiştir.

Ebüssuûd Efendi'nin (v. 982/1574) el-Marûzât isimli eserinde de bu yönde fetva verilmiştir. Buna göre sermaye sahibi mudâribi başka şehre gitmemesini şart koşsa ve bunun üzerine mudârib başka şerhe gitse mudâbirin sermayeyi tazmin etmesi gerektiği ifade

\footnotetext{
40 Çavuşzade, Dürrü's-sukuk., 2/173. Örnekleri için ayrıca bkz. Nasi Aslan, Kayseri Seriye Sicillerindeki Hicri 2084, 1087 Tarihli 81 ve 84 Numaralı Defterler ve İslam Hukuku Açısından Taahlili (Kayseri: Erciyes Üniversitesi Sosyal Bilimler Enstitüsü, 1995), 450.

41 İstanbul Kadı Sicilleri Ahi Çelebi Mahkemesi 1 Numaralı Sicil (H. 1063-1064 / M. 1652-1653), haz. Rıfat Günalan, İSAM Yayınlar1, İstanbul:2010, 49/129. Hüküm no: 140, Orijinal metin no: [22a-1]

${ }^{42}$ Mevsîlî, el-íhtiyâr, 3/13.
} 
edilmiştir. Ebüssuûd Efendi'nin başka bir ifadesine göre sermaye sahibi ile mudârib arasında ihtilafa düşseler, sermaye sahibi mudâbiri deniz seferinden men' ettiğini iddia etse, mudârib de aksini iddia etse, mudâribten yemin talep edilir ve bu yeminle lehine hüküm verilir. ${ }^{43}$

Ali Haydar Efendi (v. 1935) de sermaye sahibi ile mudâribin, mudârabe akdinin mutlak mi yoksa mukayyet mi olduğu noktasında ihtilaf etmeleri halinde ikisinin de delili yoksa yemin etmesi şartıyla mudâribin sözünün dikkate alınacağını ifade etmiştir. Bunun sebebini de mudârabe akdinde asıl olanın mutlak olması olarak açıklamaktadır. ${ }^{44}$

Osmanlı dönemindeki şeyhülislam fetvalarında da klasik teoriye uygun olarak kusuru olmaksızın mudârabe ortaklığının sermayesi mudâribin elinde zayi olsa mudâribin sorumluluğunun olmadiğı ifade edilmiştir. ${ }^{45}$

Sermaye sahibinin ihtimale binaen mudâribten kâr istemesinin meşrû olmadığı ifade edilmiştir. Şöyle ki sermaye sahibi sermayesini çalıştırması için mudâribe teslim etse, mudârib de parayı teslim alsa ancak parayı işletmese sermaye sahibinin sermaye çalıştırılsa belli miktarda kâr yapardı diyerek mudâribten kâr namına herhangi bir para alamayacağına hükmedilmiştir. ${ }^{46}$ Osmanlı döneminde kaleme alınan fetva kitaplarında da zararın mutlak manada sermaye sahibine ait olduğu vurgulanmıștır. ${ }^{47}$

Osmanlı şer'iye sicillerine yer alan kayıtlara göre mudâribin kâr etmediğini ileri sürerek dava ile ilgili herhangi bir ödemeden kaçınması durumunda bazen de sulh yoluna gidildiği ve anlaşmazlıkların bu yolla giderildiği görülür. ${ }^{48}$

\section{Değerlendirme ve Sonuç}

Mudârabe ortaklığı, ortaklık türleri içinde en çok tercih edilenler arasında yer almaktadır. Bu şirket türünün mahiyet itibarıyla bazı muhtelif hükümlere tâbi olduğu kabul edilmektedir. Buna göre çalışma sonucunda ulaşılan sonuçlar şu şekilde özetlenebilir.

1- Mudârabe ortaklığı başlangıç itibarıyla emanet hükümlerine tâbidir. Buna göre sermaye sahibi malını mudâribe teslim ettikten sonra mudâribin kusuru olmaksızın malın helak olması durumunda mudâribin tazmin sorumluluğu söz konusu olmadığından zarar sermaye sahibine aittir.

2- Mudârabe ortaklığı için malın teslim edilip mudâribin parayı işletmeye başlamasıyla vekalet hükümleri geçerlidir. $\mathrm{Bu}$ aşamada da zarar edilmesi durumunda mudâribin sorumluluğu bulunmayıp zarar sermaye sahibine aittir. Zira mudârib vekil konumundadır.

3- Mudârabe ortaklığ sonucunda kâr elde edilirse ortaklık olarak kabul edilir ve kâr paylaş1lır. Buna göre bu iş birliği neticesinde kâr elde edilirse mudârib ortak kabul edilmektedir. Dolayısıyla kâr elde edilmezse bu işlem ortaklık olarak değerlendirilmemektedir.

\footnotetext{
${ }^{43}$ Muhammed Ebüssuûd Efendi, Marûzât, ed. Pehlül Düzenli (İstanbul: Klasik Yayınları, 2013), 163. Ali Efendi, Açılamalı Osmanlı fetvâları: Fetâvâ-yı Ali Efendi (1674-1686), çev. H. Necati Demirtaş (İstanbul: Kubbealtı Akademisi Kültür ve Sanat Vakfı, 2014), 2/200. Mehmed Ziyaeddin, Osmanlı hukuk sözlüğü: mükemmel ıstılâhât-ı kavânin yâhut mâlûmât-ı kanûniye hülâsası, çev. Gedikli Fethi - Onat İbrahin Enes (İstanbul: On İki Levha Yayınc1lık, 2017), 164.

${ }^{44}$ Ali Haydar, Dürerü'l-Hukkam, 3/425.

45 Ali Efendi, Fetâvâ-yı Ali Efendi, 2/198.

${ }^{46}$ Ali Efendi, Fetâvâ-yı Ali Efendi, 2/201.

47 Avc1, Türk Hukuk Tarihi, 522.

${ }^{48}$ Aslan, Kayseri SSeriye Sicilleri, 427.
} 
Bazı müsteşriklerce ifade edilen mudârabenin hile-i şer'iye olduğu iddiası tartışmaya açıktır. Zira bu iddia gerek teorik anlamda gerekse uygulama dikkate alındığında vakıaya ters düşer. Zira bilinmektedir ki doktrinde sermaye sahibi sadece kâr elde etmeyi şart koşarsa mudârabe ortaklığı fasit olur. Uygulamada ise şer'iye sicillerine bakıldığında fiili olarak işleyen en yaygın ortaklık şeklinin mudârabe olduğu görülür. Ve işletmeden doğan anlaşmazlıkların ayrıntılarıyla yargıya yansımış olması bu iddiayı çürütmektedir. Fakat böyle bir iddia murâbahaya dönük olsa kısmen anlaşılabilirdi. Zira şer'iye sicillerinde yer alan kayıtlar bu iddiayı bütünüyle nefyetmemektedir. Buradan da anlaşılan iddia sahibi bu eleştirisini murâbaha yerine mudârabeye yöneltmiş ve kavramları karıştırmıştır.

Doktrinde hâkim kanaat göre mudârabede zarar da ortaklar arasında paylaşılmaktadır. Zira mutlak mudârabede belirlenen zamanın sonunda hiç kâr elde edilmemiş veya zarar meydana gelmiş ise sermayeyi işleten emeği karş1lığ olarak alacak olduğu kâr payından yoksun kalmak suretiyle zarara ortak olmuş kabul edilir. Ancak bu anlayışa dayanarak mudârib büyük sermayenin söz konusu olduğu bir durumda kendisinin harcadığı emeğin sermayeye oranla düşük olması halinde kâr etmediği iddiasında bulunabilir. Bu da meselenin suiistimale açık olduğunu göstermektedir.

Mudârabe ortaklığının uygulamasına bakıldığında birçok problemlere neden olan ve inisiyatifi daima mudâribe teslim eden anlayış araştırıldığında bunun esasının fıkıh usülündeki 1stıshâbü'l-hal ilkesine dayandığı görülür. Buna göre mudârib bu ortaklıkla ilgili hiç kâr etmediğini söylese onun sözüne itibar edilmesi gerekmektedir. Çünkü aslolan kârın olmamasıdır. Bu esasa göre öteden beri devam eden kârın yokluğudur. Ancak bunun hilafına bir delil sabit olduysa o zaman kârın varlığına hükmedilir. İşte bu anlayış gerek teorik açıdan gerekse uygulamada mudârabe ile ilgili birçok problemlere yol açmış ve meselenin en zayıf noktasinı oluşturmuştur.

Öteden beri yerleşik hale gelen bu tutumda ciddi bir tenakuzun olduğu da söylenebilir. Zira fikıh usulünde istishâb ilkesi delillerin en zayıfı olarak kabul edilmişken, bu ilkeye binaen zararın her durumda sermaye sahibine yüklenmesi gibi dâimi ve değişmez bir ilke vaz edilmiş olması düşündürücüdür. Burada konuya çok yönlü bakılarak yine istishâb ilkesinden hareket edilip bu meselenin vasıf istishâbına dahil edilmesi mümkün ve daha makul bir yol olabilir. Zira bu yaklaşım mal sahibini de koruyacak normatif bir ilkenin geliştirilmesinde daha etkili olabilir. Bilindiği üzere vasıf istishâbı, istishâb çeşitleri içinde en güçlü olanıdır. Bu açıdan meseleye şöyle bakılması da mümkündür. Ticaretle uğraşıp belli bir tecrübeden sonra tacir vasfını kazanmış olmak vasıf istishâbının bir gereğidir. Örfen bu vasfı kazanan bir tacirden kâr etmesi beklenir. Onun zarar etmesi ise arizî bir durumdur. Buradan hareketle mudârib ile mal sahibinin aralarında kar-zarar anlaşmazlığına dönük bir davada zararın taraflar arasında paylaşılması mümkün görülmelidir. Netice itibarıyla böyle bir yaklaşım inisiyatifin tamamen mudâribin uhdesine verilmesini önleyecektir.

Osmanlı uygulamasında ileride doğabilecek anlaşmazlıklara meydan vermemek için mudârabe akdinin kuruluşunda sermaye miktarı, kâr oranı gibi ortaklığa dair hususları içeren bir sözleşme yapıldığı ve tarafların buna dair kadıdan hüccet tanzim ettirerek kayıt 
altına aldıkları görülmektedir. Uygulamaya bakıldığında sermaye sahiplerinin ticari işleyişi kontrol ettikleri, zaman zaman muhasebe yaptıkları ve ileride doğabilecek davada dermeyan edilmek üzere şahit tuttukları ve bunu zapta geçirdikten sonra fesih cihetine gidildiğinde ilgili şahitleri ispat vesilesi olarak kullanıp sermaye ve kârlarını koruma yoluna gittikleri görülmektedir. 
Mudârabe Akdinde Ortaya Çıkan Anlaşmazlıkların Çözümünde Esas Alınan İlkeler -Osmanlı Uygulamaları Özelinde- Nasi ASLAN, Hasan KAYAPINAR

\section{Kaynakça}

Ali Efendi. Açılamalı Osmanlı fetvâları: Fetâvâ-yı Ali Efendi (1674-1686). çev. H. Necati Demirtaş. İstanbul: Kubbealtı Akademisi Kültür ve Sanat Vakfı, Birinci bask1., 2014.

Ali Haydar, Efendi. Dürerü'l-Hukkam Şerhu Mecelleti'l-Ahkam. çev. Raşit Gündoğdu - Osman Erdem. İstanbul: Osmanlı Yayınevi.

Aslan, Nasi. Kayseri Şeriye Sicillerindeki Hicri 2084, 1087 Tarihli 81 ve 84 Numaralı Defterler ve İslam Hukuku Açısından Taahlili. Kayseri: Erciyes Üniversitesi Sosyal Bilimler Enstitüsü, 1995.

Avc1, Mustafa. Türk Hukuk Tarihi. Konya: Atlas Akademi, 2017.

Bayındır, Servet. İslam Hukuku Penceresinden Faizsiz Bankacılık. İstanbul: Rağbet Yayınları, 2005.

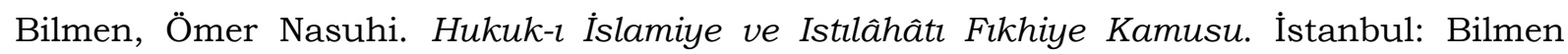
Yayınevi, 1976.

Buhârî, Ebû Abdullah Muhammed b. İsmail. Sahîh'ül-Buhârî. ed. Halil b. Me'mun Şiha. Beyrut: Daru'1-Marife, 2010.

Çavuşzade, Mehmed Aziz. Dürrü's-sukuk. İstanbul: Matbâa-i Âmire, 1288.

Çizakça, Murat. Risk Sermayesi Özel Finans Kurumları ve Para Vakıfları. İstanbul: İslami İlimler Araştırma Vakfı, 1993.

Ebüssuûd Efendi, Muhammed. Ma'rûzât. ed. Pehlül Düzenli. İstanbul: Klasik Yayınları, 2013.

Efendi, Asım. el-Okyânûsu'l-Basît fì Tercemeti'l-Kâmûsi'l-Muhît Kâmûsu'l-Muhît Tercümesi. ed. Mustafa Koç. İstanbul: Türkiye Yazma Eserler Kurumu Başkanlığı, 2012.

Gözübenli, Beşir. "Şirket”. Türkiye Diyanet Vakfi İslam Ansiklopedisi. 39/198-201. İstanbul: TDV Yayınları, 2010.

Habergetiren, Ömer Faruk. "Mecelle Şârihi Ali Haydar Efendi ve "Mefkûd Risâlesi"”. İslam Hukuku Araştırmaları Dergisi 22 (2013), 493-516.

Kahveci, Nuri. Mukayeseli İslam Borçlar Hukuku (Şirketler İlaveli). İstanbul: Hikmetevi Yayınları, 2015.

Kâsânî, Ebû Bekr Alaeddin Ebû Bekr b. Mes'ud b. Ahmed. Bedâiü's-Sanâi' fí Tertibi'ş-Şerai'. ed. Ali Muhammed Muavvad. Beyrut: Dar'ul-Kütübi'1-İlmiye, 2003.

Kudûrî, Ebü'l-Hüseyin Ahmed b. Ebî Bekr Muhammed b. Ahmed el-. el-Muhtasar. ed. Kami Muhammed Muhammed Avida. Beyrut: Daru'l-Kütübi'l-İlmiye, 1997.

Mevsîlî, Ebü'l-Fazl Mecdüddin Abdullah b. Mahmûd b. Mevdud. el-íhtiyâr li-Ta'lîli'l-Muhtâr. ed. Halid Abdurrahman el-Akk. Beyrut: Daru'l-Marife, 2007.

Meydanî, Abdülganî b. Talib b. Hammade ed-Dımaşki. el-Lübâb fi Şerhi'l-Kitâb. ed. Abdürrezzâk el-Mehdi. Beyrut: Dârü'l-Kitâbi'l-Arabî, 2012.

Râgıb El-İsfahânî, Ebû'l-Kâsım Hüseyn b. Muhammed b. er-. el-Müfredât fí Garîbi'l-Kur'ân. thk. Șafvân 'Adnan ed-Dâvûdî. Dımaşk: Daru'l-Ḳalem;Daru'ş-Şâmiyye, ts.

Schacht, Joseph. İslam Hukukuna Giriş, çev. Mehmet Dağ, Abdülkadir Şener, Ankara Üniversitesi İlahiyat Fakültesi Yayınları, Anraka 1977. 
Semerkandî, Ebû Bekr Alaeddin Muhammed b. Ahmed b. Ebû Ahmed. Tuhfetül-Fukahâ. Beyrut: Daru'1-Kütübi'l-İlmiye, 1983.

Serahsi, Ebû Bekr Şemsüleimme Muhammed b. Ahmed b. Sehl. el-Mebsut. Beyrut: Daru'1Marife, ts.

Şirâzî, Ebû İshak Cemaleddin İbrâhim b. Ali b. Yusuf. el-Mühezzeb fî Fıkhi’l-İmam eş-Şafî̀. ed. Zekeriya Umeyrat. Beyrut: Dârü'l-Kütübü'l-İlmiye, 1995.

Şirbînî, Şemseddin Hatib Muhammed b. Ahmed. Muğni'l-Muhtac ila Marifeti Meânî Elfazi’lMinhac. ed. Muhammed Halil Îtânî. Beyrut: Daru'l-Marife, 1997.

Tahâvî, Ebû Ca'fer Ahmed b. Muhammed b. Selâme. Muhtasarü't-Tahâvî. ed. Ebü'l-Vefâ elEfganî. Kahire: Dârü'l-Kitâbi'l-Arabi, 1370.

Zebîdî, Ebü'l-Feyz Muhammed el-Murtazâ b. Muhammed b. Muhammed b. Abdirrezzâk ez-. Tâcu'l Arûs Min Cevâhiri'l Kâmûs. ed. Mustafa Hicâzî. Kuveyt: Daru Türasi'l-Arabî, 1993.

Zeydan, Abdülkerim. el-Vecîz fi Usûli’l-Fıkh. Dimaşk: Müessetü'r-Risale, 2006.

Ziyaeddin, Mehmed. Osmanlı hukuk sözlüğü: mükemmel ıstılâhât-ı kavânin yâhut mâlûmât-ı kanûniye hülâsası. çev. Gedikli Fethi - Onat İbrahin Enes. İstanbul: On İki Levha Yayınc1lik, 2017. 


\title{
THE PRINCIPLES FOR THE RESOLUTION OF THE DISPUTES ARISING IN THE MUDARABAH CONTRACT - BASED ON THE OTTOMAN PRACTICES -
}

\begin{abstract}
The phenomenon of business partnership has been around since ancient times and practiced in the history of Islam since the time of the Prophet (PBUH). There is no dispute regarding the legitimacy of a business partnership or a company within this historical experience. Mudarabah, which is a type of partnership in general terms, can also be considered in this context.

Mudarabah, as a term, refers to a business partnership and is a type of company in which one of the partners gives money to the other for investing in a commercial enterprise. Regarding the legal position of Mudarabah, Hanafi sources emphasize that this type of partnership is against qiyas. Thus, the legitimacy of the mudarabah is dependent on istihsan based on some special evidence. The Mudarabah Contract contains different types of contracts in its composition. When the capital of the owner is entrusted with the mudarib, the money becomes the amanat; When the mudarib starts to trade with the capital, the mudarib becomes the wakil; When a profit is obtained as a result of the partnership, the mudarib becomes a shareholder.

As mentioned in the works of fiqh, when the goods or the capital are delivered to the mudarib party, the provisions of amanat apply to this property. Accordingly, in case of an unintentional loss of mudarabah property, the mudarib party cannot be held responsible. In this case, the loss will belong to the capital owner. Furthermore, when deciding whether there was a profit or not, the mudarib party's statement was deemed valid and it was the responsibility of the owner (rabb-ul-mal) to prove otherwise.

In the study, in addition to the theory, the mudarabah practices in the Ottoman Empire were examined through the provisions and debates regarding the mudarabah partnerships reflected in the qadi registers and fatwa books. In particular, the principles to be taken as a basis in case of disagreement were emphasized.

The Mudarabah partnership does not require a detailed procedure in practice. On the other hand, it is a frequently chosen type of company because it brings together people with different abilities and opportunities, that is, people who cannot deal with trade despite having capital, and people who have commercial skills but do not have capital or goods. As a matter of fact, when looking at the Ottoman shariah registers, it can be seen that mudarabah was the most common partnership practice.

Looking at the functioning of the Mudarabah partnership, it can be argued that it has some problems. Accordingly, it can be seen that the initiative always belongs to the mudarib, and this is based on the principle of istishab al-hal in figh. That is, if the mudarib states that there was no profit, his word should be respected. As the profit has not existed in the past, it is presumed to be non-existent until the contrary is proven. However, if there is evidence against this, then it is judged that there is profit. This issue is the weakest point of the mudarabah practice as it causes many problems both theoretically and in practice. As a result, instead of being the sole risk-taker, capital owners may prefer the murabaha partnership, which does not contain similar risk elements. Thus, as can be seen in the records regarding Ottoman practices on the subject, it is understandable that the murabaha partnerships were preferred the most.
\end{abstract}

Keywords: İslamic Law Company, Mudarabah, Istishab, Ottoman Practices 